\title{
THE INFLUENCE OF COPTISINE BISULFATE ON THE EVOLUTION OF ACUTE TOXIC HEPATITIS
}

\author{
Peredelcu Rodica, assistant \\ Gonciar Veaceslav, PhD, professor \\ Scutari Corina, scutari Corina, PhD, associate professor \\ Cazacu Vasile, $P h D$, associate professor
}
Republic of Moldova, Chisinau, Departement of Pharmacology and Clinical Pharmacy of SUMPh Nicolae Testemitanu

DOI: https://doi.org/10.31435/rsglobal_ws/30082018/6065

\section{ARTICLE INFO}

Received: 13 July 2018

Accepted: 21 August 2018

Published: 30 August 2018

\section{KEYWORDS}

coptisine bisulfate, toxic hepatitis, alanine aminotransferase. aspartate aminotransferaze, cytolysis,

cholestasis,

liver.

\begin{abstract}
In the experiments made on white rats was studied the influence of coptisine bisulfate, alkaloid extracted from Chelidonium majus, in the following doses: $10 \mathrm{mg} / \mathrm{kg}$ and $20 \mathrm{mg} / \mathrm{kg}$ on acute toxic hepatitis cause by carbon tetrachloride. It was established that the researched substance reduced hepatic cytolysis and cholestasis through reestablishment of the transaminases activity and lactate dehydrogenase, while lowering the alkaline phosphatase/alanine aminotransferase ratio and modulated the deflection of the metabolic parameters of acute toxic hepatitis. Coptisine bisulfate corrected the carbon tetrachloride caused hypoproteinemia when administered for 7 days and normalized the albumin level at 14th day of treatment of acute toxic hepatitis.
\end{abstract}

Citation: Peredelcu Rodica, Gonciar Veaceslav, Scutari Corina, Cazacu Vasile. (2018) The Influence of Coptisine Bisulfate on the Evolution of Acute Toxic Hepatitis. World Science. 8(36), Vol.2. doi: 10.31435/rsglobal_ws/30082018/6065

Copyright: (C) 2018 Peredelcu Rodica, Gonciar Veaceslav, Scutari Corina, Cazacu Vasile. This is an open-access article distributed under the terms of the Creative Commons Attribution License (CC BY). The use, distribution or reproduction in other forums is permitted, provided the original author(s) or licensor are credited and that the original publication in this journal is cited, in accordance with accepted academic practice. No use, distribution or reproduction is permitted which does not comply with these terms.

Introduction. Hepatoprotective activity of Chelidonium majus shows benefic influence on the liver functions due to isoquinoline derivatives with antioxidant, choleretic, anti inflammatory and immunomodulatory effects, one of them being coptisine [2, 5]. Chelidonium majus ethanolic extract proved the capacity of reducing the hepatotoxicity induced by carbon tetrachloride, through lowering the lipids cumulation, celular necrosis grouth and the lack of [6].

A certain amount of clinical studies that contain extracts from the patients with biliary tract and gallbladder disorders (gallstones, cholecystitis, cholangitis, postcholecystectomy syndrome, alcoholic toxic hepatitis) sugested a significant improvement of the clinical, instrumental and laboratory parameters (bilirubin, transaminases, complete blood count) [6].

Coptisine bisulfate, presented at the Medicine Scientific Centre, USMF "Nicolae Testemițanu" [1] was obtained from Celandine herbs.

Scientific literature analisis allow us to conclude that extract and alkaloids of Chelidonium majus manifests hepatoprotective activity through: decreasing the production of the reactive species of Oxygen; inhibition of the lipids peroxidation; glutathione synthesis rise and antioxidant enzyme activity; reduction of the inflammatory process due to decreasing of proinflammatory cytokines production; correction of lipidic metabolism disorders.

Due to the lack of coptisine bisulfate toxicity [3, 4], compared with berberin and other alkaloids of Chelidonium majus and considering the hepatoprotective effect, it was established the aim of experimental research of coptisine bisulfate on acute toxic hepatitis (ATH) shaped in white rats by administering carbon tetrachloride. 
Results. Using coptisine bisulfate in the treatment of ATH, there were studied the influence of this alkaloid on the evolution of acute hepatic lesion when using 10 and $20 \mathrm{mg} / \mathrm{kg}$ strenghts for establishing a strengh- hepatoprotective effect dependency.

When shaping ATH using $\mathrm{CCl}_{4}$ at the 7th day it was observed a growing of AlAT from $56,8 \pm 2,4 \mathrm{mmol} / \mathrm{l}$ to $190,6 \pm 8,2 \mathrm{mmol} / \mathrm{l}\left(\mathrm{P}_{1-2<0,05}\right)$ and AsAT - from $140,2 \pm 5,0 \mathrm{mmol} / \mathrm{l}$ to $260,2 \pm 20,5$ $\mathrm{mmol} / \mathrm{l}(\mathrm{P}<0,05)$. This growing of the transaminase level is still manifesting after 2 weeks after the hepatotoxic was administered (tab.1). In these condition were determined a reduction of Ritis coefficient from 2,46 $\pm 0,21$ to $1,36 \pm 0,25$. Coptisine bisuflate administration in $10 \mathrm{mg} / \mathrm{kg}$ and $20 \mathrm{mg} / \mathrm{kg}$ strenghts for 7 and 14 days contributed to maintaining of AlAT and AsAT levels and Ritis coefficient, basically at the position of witness lot (tab. 1).

Tabel 1. Modification of transaminase level in serum in carbon tetrachloride induced HT and coptisine bisulfate 10 and $20 \mathrm{mg} / \mathrm{kg}$ usage

\begin{tabular}{|c|c|c|c|c|}
\hline Animal groups & $\begin{array}{c}\text { Nr.of } \\
\text { animals }\end{array}$ & $\begin{array}{r}\text { AlAT } \\
\mathrm{mmol} / \mathrm{l}\end{array}$ & $\begin{array}{r}\text { AsAT } \\
\text { mmol/l }\end{array}$ & $\begin{array}{c}\text { Ritis } \\
\text { coefficient }\end{array}$ \\
\hline 1. Witness lot & 10 & $56,8 \pm 2,4$ & $140,2 \pm 5,0$ & $2,46 \pm 0,21$ \\
\hline 2. $\mathrm{CCl}_{4}$ after 7 days & 10 & $\begin{array}{l}190,6 \pm 8,2 \\
\mathrm{P}_{1-2<0,05}\end{array}$ & $\begin{array}{l}260,2 \pm 20,5 \\
P_{1-2<0,05}\end{array}$ & $\begin{array}{l}1,36 \pm 0,25 \\
P_{1-2<0,05}\end{array}$ \\
\hline $\begin{array}{l}\text { 3. } \mathrm{CCl}_{4}+\text { coptisine bisulfate } 10 \mathrm{mg} / \mathrm{kg} 7 \\
\text { days }\end{array}$ & 10 & $\begin{array}{l}60,0 \pm 1,8 \\
\mathrm{P}_{1-3>0,05} \\
\mathrm{P}_{2-3<0,05} \\
\end{array}$ & $\begin{array}{l}153,1 \pm 7,3 \\
\mathrm{P}_{1-3>0,05} \\
\mathrm{P}_{2-3<0,05} \\
\end{array}$ & $\begin{array}{l}2,55 \pm 0,4 \\
\mathrm{P}_{1-3>0,05} \\
\mathrm{P}_{2-3<0,05} \\
\end{array}$ \\
\hline $\begin{array}{l}\text { 4. } \mathrm{CCl}_{4}+\text { coptisine bisulfate } 20 \mathrm{mg} / \mathrm{kg} 7 \\
\text { days }\end{array}$ & 10 & $\begin{array}{l}65,4 \pm 4,9 \\
P_{1-4<0,05} \\
P_{2-4>0,05} \\
P_{3-4>0,05}\end{array}$ & $\begin{array}{l}153,2 \pm 8,6 \\
\mathrm{P}_{1-4>0,05} \\
\mathrm{P}_{2-4<0,05} \\
\mathrm{P}_{3-4>0,05}\end{array}$ & $\begin{array}{l}2,34 \pm 0,18 \\
\mathrm{P}_{1-4>0,05} \\
\mathrm{P}_{2-4<0,05} \\
\mathrm{P}_{3-4>0,05}\end{array}$ \\
\hline 5. $\mathrm{CCl}_{4}$ after 14 days & 10 & $\begin{array}{l}223,4 \pm 6,9 \\
\mathrm{P}_{1-5<0,05}\end{array}$ & $\begin{array}{l}440,4 \pm 29,7 \\
P_{1-5<0,05}\end{array}$ & $\begin{array}{l}1,97 \pm 0,44 \\
P_{1-5<0,05}\end{array}$ \\
\hline $\begin{array}{l}\text { 6. } \mathrm{CCl}_{4}+\text { coptisine bisulfate } 10 \mathrm{mg} / \mathrm{kg} \\
14 \text { days }\end{array}$ & 10 & $\begin{array}{l}59,6 \pm 0,9 \\
\mathrm{P}_{1-6>0,05} \\
\mathrm{P}_{5-6<0,05} \\
\end{array}$ & $\begin{array}{l}128,1 \pm 3,9 \\
\mathrm{P}_{1-6>0,05} \\
\mathrm{P}_{5-6<0,05} \\
\end{array}$ & $\begin{array}{l}2,15 \pm 0,43 \\
P_{1-6>0,05} \\
P_{5-6>0,05}\end{array}$ \\
\hline $\begin{array}{l}\text { 7. } \mathrm{CCl}_{4}+\text { coptisine bisulfate } 20 \mathrm{mg} / \mathrm{kg} \\
14 \text { days }\end{array}$ & 10 & $\begin{array}{l}66,6 \pm 3,5 \\
\mathrm{P}_{1-7>0,05} \\
\mathrm{P}_{5-7<0,05} \\
\mathrm{P}_{6-7>0,05}\end{array}$ & $\begin{array}{l}144,5 \pm 6,1 \\
P_{1-7>0,05} \\
P_{5-7<0,05} \\
P_{6-7>0,05}\end{array}$ & $\begin{array}{l}2,15 \pm 0,17 \\
P_{1-7>0,05} \\
P_{5-7>0,05} \\
P_{6-7>0,05}\end{array}$ \\
\hline
\end{tabular}

When injected $\mathrm{CCl}_{4}$ at the 7th day it was determined a growth of alkaline phosphatase activity from $510,2 \pm 23,3 \mathrm{UI} / \mathrm{l}$ in the witness lot to $1063,7 \pm 57,5 \mathrm{UI} / \mathrm{l}(\mathrm{P}<0,05)$. When using coptisine bisulfate in doses $10 \mathrm{mg} / \mathrm{kg}$ and $20 \mathrm{mg} / \mathrm{kg}$ for 7 days there was noticed a decreased level of alkaline phosphatase level comparing with the ATH lot, which was non significantly higher than the witness lot. When shaping the experimental hepatitis at 14th day it was noticed that alkaline phosphatase content was 784,4 $\pm 62,7 \mathrm{UI} / \mathrm{l}$ compared to $510,2 \pm 23,3 \mathrm{UI} / \mathrm{l}(\mathrm{P}<0,05)$ in the witness lot, but lower than

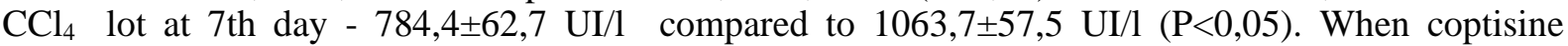
bisulfate was administered in both doses there were no esential changes to the lot with $\mathrm{CCl}_{4}$ after14 days determined (tab. 2).

When ATH was shaped at the 7th day was determined a decreasing of the acidic phosphatase from 4,8 $\pm 0,3 \mathrm{UI} / \mathrm{l}$ in the witness lot to $3,7 \pm 0,3 \mathrm{UI} / \mathrm{l}(\mathrm{P}<0,05)$, which was maintained at the same level at 14th day as well. When coptisine bisulfate was administered for 7 days in the doses $10 \mathrm{mg} / \mathrm{kg}$ and $20 \mathrm{mg} / \mathrm{kg}$ it was established a significant reduction of the acidic phosphatase level in the witness lot, and in the experimental hepatitis one as well. When the alkaloid was used for 2 weeks in both strenghts the acidic phosphatase content increased from 3,7 $\pm 0,3 \mathrm{UI} / \mathrm{l}$ in the lot with $\mathrm{CCl}_{4}$ to $4,2 \pm 0,4$ $\mathrm{UI} / \mathrm{l}$ at the dose of $10 \mathrm{mg} / \mathrm{kg}$ and 4,1 $\pm 0,3 \mathrm{UI} / \mathrm{l}$ at the dose of $20 \mathrm{mg} / \mathrm{kg}(\mathrm{P}>0,05)$. 
Tabel 2. The modification of alkaline phosphatase activity, acidic phosphatase and GGTP in serum in carbon tetrachloride induced HT and the coptisine bisulfate 10 and $20 \mathrm{mg} / \mathrm{kg}$ usage

\begin{tabular}{|c|c|c|c|c|}
\hline Animal groups & $\begin{array}{c}\text { Nr.of } \\
\text { animals }\end{array}$ & $\begin{array}{c}\text { Alkaline } \\
\text { phosphatase } \\
\text { (UI/I) }\end{array}$ & $\begin{array}{c}\text { Acidic } \\
\text { phosphatase } \\
\text { (UI/I) }\end{array}$ & GGTP \\
\hline 1. The witness lot & 7 & $510,2 \pm 23,3$ & $4,8 \pm 0,3$ & $3,7 \pm 0,4$ \\
\hline 2. $\mathrm{CCl}_{4}$ after 7 days & 7 & $\begin{array}{l}1063,7 \pm 57,5 \\
\mathrm{P}_{1-2<0,05}\end{array}$ & $\begin{array}{l}3,7 \pm 0,3 \\
P_{1-2<0,05}\end{array}$ & $\begin{array}{l}3,6 \pm 0,3 \\
P_{1-2>0,05}\end{array}$ \\
\hline $\begin{array}{l}\text { 3. } \mathrm{CCl}_{4}+\text { coptisine bisulfate } 10 \mathrm{mg} / \mathrm{kg} \\
7 \text { days }\end{array}$ & 7 & $\begin{array}{l}862,3 \pm 49,7 \\
\mathrm{P}_{1-3>0,05} \\
\mathrm{P}_{2-3<0,05}\end{array}$ & $\begin{array}{l}2,5 \pm 0,3 \\
\mathrm{P}_{1-3<0,05} \\
\mathrm{P}_{2-3<0,05}\end{array}$ & $\begin{array}{l}4,3 \pm 0,7 \\
\mathrm{P}_{1-3>0,05} \\
\mathrm{P}_{2-3>0,05}\end{array}$ \\
\hline $\begin{array}{l}\text { 4. } \mathrm{CCl}_{4}+\text { coptisine bisulfate } 20 \mathrm{mg} / \mathrm{kg} \\
7 \text { days }\end{array}$ & 7 & $\begin{array}{l}783,4 \pm 53,3 \\
\mathrm{P}_{1-4>0,05} \\
\mathrm{P}_{2-4<0,05} \\
\mathrm{P}_{3-4>0,05}\end{array}$ & $\begin{array}{l}2,9 \pm 0,3 \\
\mathrm{P}_{1-4<0,05} \\
\mathrm{P}_{2-4>0,05} \\
\mathrm{P}_{3-4>0,05}\end{array}$ & $\begin{array}{l}3,4 \pm 0,2 \\
\mathrm{P}_{1-4>0,05} \\
\mathrm{P}_{2-4>0,05} \\
\mathrm{P}_{3-4>0,05}\end{array}$ \\
\hline 5. $\mathrm{CCl}_{4}$ after 14 days & 7 & $\begin{array}{l}784,4 \pm 62,7 \\
P_{1-5<0,05}\end{array}$ & $\begin{array}{l}3,7 \pm 0,3 \\
P_{1-5<0,05}\end{array}$ & $\begin{array}{l}6,7 \pm 0,7 \\
P_{1-5<0,05}\end{array}$ \\
\hline $\begin{array}{l}\text { 6. } \mathrm{CCl}_{4}+\text { coptisine bisulfate } 10 \mathrm{mg} / \mathrm{kg} \\
14 \text { days }\end{array}$ & 7 & $\begin{array}{l}790,5 \pm 47,7 \\
\mathrm{P}_{1-6>0,05} \\
\mathrm{P}_{5-6>0,05}\end{array}$ & $\begin{array}{l}4,2 \pm 0,4 \\
\mathrm{P}_{1-6>0,05} \\
\mathrm{P}_{5-6>0,05}\end{array}$ & $\begin{array}{l}4,1 \pm 0,4 \\
P_{1-6>0,05} \\
P_{5-6<0,05}\end{array}$ \\
\hline $\begin{array}{l}\text { 7. } \mathrm{CCl}_{4}+\text { coptisine bisulfate } 20 \mathrm{mg} / \mathrm{kg} \\
14 \text { days }\end{array}$ & 7 & $\begin{array}{l}711,9 \pm 53,2 \\
\mathrm{P}_{1-7>0,05} \\
\mathrm{P}_{5-7>0,05} \\
\mathrm{P}_{6-7>0,05}\end{array}$ & $\begin{array}{l}4,1 \pm 0,3 \\
\mathrm{P}_{1-7>0,05} \\
\mathrm{P}_{5-7>0,05} \\
\mathrm{P}_{6-7>0,05}\end{array}$ & $\begin{array}{l}4,2 \pm 0,5 \\
\mathrm{P}_{1-7>0,05} \\
\mathrm{P}_{5-7<0,05} \\
\mathrm{P}_{6-7>0,05}\end{array}$ \\
\hline
\end{tabular}

In ATH, induced by $\mathrm{CCl}_{4}$, activity of GGTP did not change significantly at the 7th day, but increased a lot at the 14th day (tab. 2). When coptisine bisulfate was administered in the dose of 10

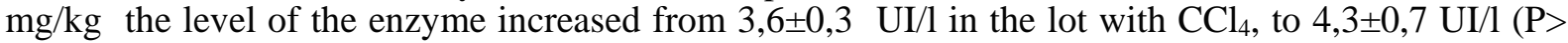
$0,05)$, while the alkaloid in the dose of $20 \mathrm{mg} / \mathrm{kg}$ was decreasing snonsignificantly the content of GGTP (tab. 2). The usage of the alkaloid for 2 weeks contributed to diminishing of the GGTP level from $6,7 \pm 0,7 \mathrm{UI} / \mathrm{l}$ int he lost with experimental hepatitis, to $4,1 \pm 0,4 \mathrm{UI} / \mathrm{l}$ and $4,2 \pm 0,5 \mathrm{UI} / \mathrm{l}(\mathrm{P}<0,05)$ in doses of $10 \mathrm{mg} / \mathrm{kg}$ and $20 \mathrm{mg} / \mathrm{kg}$ accordingly.

In the process of shaping the experimental hepatitis at the 7th day there was noticed a tendency of growing the bilirubin total level in rats from $40,1 \pm 2,6 \mathrm{mmol} / \mathrm{l}$ to $44,2 \pm 3,6 \mathrm{mmol} / \mathrm{l}$ $(\mathrm{P}>0,05)$, direct bilirubin from $23,0 \pm 1,4 \mathrm{mmol} / \mathrm{k}$ to $26,3 \pm 2,7 \mathrm{mmol} / \mathrm{l}(\mathrm{P}>0,05)$ and indirect bilirubin from $17,1 \pm 1,3 \mathrm{mmol} / \mathrm{l}$ to $17,9 \pm 1,6 \mathrm{mmol} / \mathrm{l} \quad(\mathrm{P}>0,05)$. When coptisine bisulfate was administered in the doses of $10 \mathrm{mg} / \mathrm{kg}$ and $20 \mathrm{mg} / \mathrm{kg}$ for 7 days there were no main changes in the total bilirubin content and its fractions (tab. 3). After 14 days there were no significant diversion in total, direct and indirect bilirubin level in comparison with the witness lot, in animals with ATH. Coptisine bisulfate, used for 2 weeks, both strenghts, did not influence the content of bilirubin and its fractions (tab. 3).

Tabel 3. The modification of the total, direct and indirect bilirubin level in serum in carbon tetrachloride induced HT and coptisine bisulfate 10 and $20 \mathrm{mg} / \mathrm{kg}$ usage

\begin{tabular}{|l|c|c|c|c|}
\hline \multicolumn{1}{|c|}{ Animal groups } & $\begin{array}{c}\text { Nr. Of } \\
\text { ani- } \\
\text { mals }\end{array}$ & $\begin{array}{l}\text { Total bilirubin } \\
\text { mmol/l }\end{array}$ & $\begin{array}{c}\text { Direct } \\
\text { bilirubin } \\
\text { mmol/l }\end{array}$ & $\begin{array}{c}\text { Indirect } \\
\text { bilirubin }\end{array}$ \\
\hline 1 & 2 & 3 & 4 & 5 \\
\hline 1. The witness lot & 7 & $40,1 \pm 2,6$ & $23,0 \pm 1,4$ & $17,1 \pm 1,3$ \\
\hline 2. CCl $_{4}$ after 7 days & 7 & $44,2 \pm 3,6$ & $26,3 \pm 2,7$ & $17,9 \pm 1,6$ \\
& & $\mathrm{P}_{1-2>0,05}$ & $\mathrm{P}_{1-2>0,05}$ & $\mathrm{P}_{1-2>0,05}$ \\
\hline 3. $\mathrm{CCl}_{4}+$ coptisine bisulfate 10 $\mathrm{mg} / \mathrm{kg}$ & 7 & $42,3 \pm 3,4$ & $25,1 \pm 1,9$ & $17,2 \pm 1,9$ \\
7 days & & $\mathrm{P}_{1-3>0,05}$ & $\mathrm{P}_{1-3>0,05}$ & $\mathrm{P}_{1-3>0,05}$ \\
& & $\mathrm{P}_{2-3>0,05}$ & $\mathrm{P}_{2-3>0,05}$ & $\mathrm{P}_{2-3>0,05}$ \\
\hline 4. $\mathrm{CCl}_{4}+$ coptisine bisulfate $20 \mathrm{mg} / \mathrm{kg}$ & 7 & $47,2 \pm 2,7$ & $27,2 \pm 1,2$ & $20,0 \pm 1,7$ \\
7 days & & $\mathrm{P}_{1-4>0,05}$ & $\mathrm{P}_{1-4}$ & $\mathrm{P}_{1-4>0,05}$ \\
& & $\mathrm{P}_{2-4>0,05}$ & $\mathrm{P}_{2-4>0,05}$ & $\mathrm{P}_{2-4>0,05}$ \\
& & $\mathrm{P}_{3-4>0,05}$ & $\mathrm{P}_{3-4>0,05}$ & $\mathrm{P}_{3-4>0,05}$ \\
\hline 5. $\mathrm{CCl}_{4}$ after 14 days & 7 & $39,0 \pm 3,7$ & $22,9 \pm 1,6$ & $16,1 \pm 2,3$ \\
& & $\mathrm{P}_{1-5>0,05}$ & $\mathrm{P}_{1-5>0,05}$ & $\mathrm{P}_{1-5>0,05}$ \\
\hline
\end{tabular}


Continuation of table 3

\begin{tabular}{|l|c|c|c|c|}
\hline \multicolumn{1}{|c|}{1} & 2 & 3 & 4 & 5 \\
\hline 6. $\mathrm{CCl}_{4}+$ coptisine bisulfate $10 \mathrm{mg} / \mathrm{kg}$ & 7 & $40,6 \pm 2,2$ & $23,1 \pm 1,3$ & $17,5 \pm 1,0$ \\
& & $\mathrm{P}_{1-6>0,05}$ & $\mathrm{P}_{1-6>0,05}$ & $\mathrm{P}_{1-6>0,05}$ \\
& & $\mathrm{P}_{5-6>0,05}$ & $\mathrm{P}_{5-6>0,05}$ & $\mathrm{P}_{5-6>0,05}$ \\
\hline 7. $\mathrm{CCl}_{4}+$ coptisine bisulfate $20 \mathrm{mg} / \mathrm{kg}$ & 7 & $38,7 \pm 2,6$ & $21,9 \pm 1,1$ & $16,8 \pm 1,9$ \\
& & $\mathrm{P}_{1-7>0,05}$ & $\mathrm{P}_{1-7>0,05}$ & $\mathrm{P}_{1-7>0,05}$ \\
& & $\mathrm{P}_{5-7>0,05}$ & $\mathrm{P}_{5-7>0,05}$ & $\mathrm{P}_{5-7>0,05}$ \\
& & $\mathrm{P}_{6-7>0,05}$ & $\mathrm{P}_{6-7>0,05}$ & $\mathrm{P}_{6-7>0,05}$ \\
\hline
\end{tabular}

When determining the LDH level at the 7th day after shaping ATH it was determined a growth of LDH from 386,2 $\pm 12,8 \mathrm{UI} / \mathrm{l}$ in the witness lot to $1005,7 \pm 72,5 \mathrm{UI} / \mathrm{l}\left(\mathrm{P}_{1-2<0,05}\right)$, following to grow until $1355,7 \pm 83,7 \mathrm{UI} / \mathrm{l}(\mathrm{P}<0,05)$ in the 14th day. Whencoptisine bisulfate in strenghts of $10 \mathrm{mg} / \mathrm{kg}$ and $20 \mathrm{mg} / \mathrm{kg}$ was administered for 7 and 14 days, the LDH level was at the position of the animals in the witness lot (tab. 4).

When shaping ATH it was noticed a non esential fall of the glucose level in the 7th day and a non significant increase in the 14th day. Coptisine bisulfate, in $10 \mathrm{mg} / \mathrm{kg}$ and $20 \mathrm{mg} / \mathrm{kg}$ doses, nearly did not influence after 1 week and after 2 weeks as well, the changes of blood glucose induced by the hepatotoxic substance (tab. 4).

Tabel 4. The modification of LDH activity, glucose level and thymol reaction in carbon tetrachloride induced HT and coptisine bisulfate 10 and $20 \mathrm{mg} / \mathrm{kg}$ usage

\begin{tabular}{|c|c|c|c|c|}
\hline Animal groups & $\begin{array}{l}\text { Nr. Of } \\
\text { ani- } \\
\text { mals }\end{array}$ & $\begin{array}{c}\text { LDH } \\
\text { UI/l }\end{array}$ & $\begin{array}{l}\text { Glucose } \\
\mathrm{mmol} / \mathrm{l}\end{array}$ & $\begin{array}{l}\text { Thymol } \\
\text { reaction }\end{array}$ \\
\hline 1. The witness lot & 7 & $386,2 \pm 12,8$ & $5,2 \pm 0,3$ & $4,17 \pm 0,1$ \\
\hline 2. $\mathrm{CCl}_{4}$ after 7 days & 7 & $\begin{array}{c}1005,7 \pm 72,5 \\
\mathrm{P}_{1-2<0,05}\end{array}$ & $\begin{array}{l}4,6 \pm 0,2 \\
\mathrm{P}_{1-2>0,05}\end{array}$ & $\begin{array}{c}3,41 \pm 0,08 \\
\mathrm{P}_{1-2<0,05}\end{array}$ \\
\hline $\begin{array}{l}\text { 3. } \mathrm{CCl}_{4}+\text { coptisine bisulfate } 10 \mathrm{mg} / \mathrm{kg} 7 \\
\text { days }\end{array}$ & 7 & $\begin{array}{c}413,9 \pm 20,3 \\
\mathrm{P}_{1-3>0,05} \\
\mathrm{P}_{2-3<0,05} \\
\end{array}$ & $\begin{array}{l}4,7 \pm 0,2 \\
\mathrm{P}_{1-3>0,05} \\
\mathrm{P}_{2-3>0,05}\end{array}$ & $\begin{array}{c}, 42 \pm 0,1 \\
\mathrm{P}_{1-3<0,05} \\
\mathrm{P}_{2-3>0,05}\end{array}$ \\
\hline $\begin{array}{l}\text { 4. } \mathrm{CCl}_{4}+\text { coptisine bisulfate } 20 \mathrm{mg} / \mathrm{kg} 7 \\
\text { days }\end{array}$ & 7 & $\begin{array}{c}375,2 \pm 21,6 \\
\mathrm{P}_{1-4>0,05} \\
\mathrm{P}_{2-4<0,05} \\
\mathrm{P}_{3-4>0,05} \\
\end{array}$ & $\begin{array}{l}4,6 \pm 0,2 \\
\mathrm{P}_{1-4>0,05} \\
\mathrm{P}_{2-4>0,05} \\
\mathrm{P}_{3-4>0,05}\end{array}$ & $\begin{array}{c}3,43 \pm 0,08 \\
\mathrm{P}_{1-4<0,05} \\
\mathrm{P}_{2-4>0,05} \\
\mathrm{P}_{3-4>0,05} \\
\end{array}$ \\
\hline 5. $\mathrm{CCl}_{4}$ after 14 days & 7 & $\begin{array}{l}1355,7 \pm 83,7 \\
\mathrm{P}_{1-5<0,05}\end{array}$ & $\begin{array}{l}5,6 \pm 0,1 \\
\mathrm{P}_{1-5>0,05}\end{array}$ & $\begin{array}{c}4,19 \pm 0,12 \\
\mathrm{P}_{1-5>0,05}\end{array}$ \\
\hline $\begin{array}{l}\text { 6. } \mathrm{CCl}_{4}+\text { coptisine bisulfate } 10 \mathrm{mg} / \mathrm{kg} \\
14 \text { days }\end{array}$ & 7 & $\begin{array}{c}392,9 \pm 16,6 \\
\mathrm{P}_{1-6<0,05} \\
\mathrm{P}_{5-6<0,05}\end{array}$ & $\begin{array}{l}5,7 \pm 0,3 \\
\mathrm{P}_{1-6>0,05} \\
\mathrm{P}_{5-6>0,05}\end{array}$ & $\begin{array}{c}4,37 \pm 0,11 \\
\mathrm{P}_{1-6>0,05} \\
\mathrm{P}_{5-6>0,05}\end{array}$ \\
\hline $\begin{array}{l}\text { 7. } \mathrm{CCl}_{4}+\text { coptisine bisulfate } 20 \mathrm{mg} / \mathrm{kg} \\
14 \text { days }\end{array}$ & 7 & $\begin{array}{c}386,6 \pm 19,9 \\
\mathrm{P}_{1-7<0,05} \\
\mathrm{P}_{5-7<0,05} \\
\mathrm{P}_{6-7>0,05}\end{array}$ & $\begin{array}{l}5,7 \pm 0,3 \\
\mathrm{P}_{1-7>0,05} \\
\mathrm{P}_{5-7>0,05} \\
\mathrm{P}_{6-7>0,05}\end{array}$ & $\begin{array}{c}4,22 \pm 0,12 \\
\mathrm{P}_{1-7>0,05} \\
\mathrm{P}_{5-7>0,05} \\
\mathrm{P}_{6-7>0,05}\end{array}$ \\
\hline
\end{tabular}

Carbon tetrachloride did not influence the cholesterol total level in the 7th day, but determined a increase of it in the 14th day from $5,09 \pm 0,04 \mathrm{mmol} / \mathrm{l}$ in the witness lot to $5,28 \pm 0,05 \mathrm{mmol} / \mathrm{l}$ $(\mathrm{P}<0,05)$. Coptisine bisulfate $(10 \mathrm{mg} / \mathrm{kg}$ and $20 \mathrm{mg} / \mathrm{kg})$, administered for 7 and 14 days determined a decrease of the total cholesterol content (tab. 5).

In the experimental hepatitis were not ascertained esential changes of the total protein level, both in 7th and 14th day (tab. 5). In the same time the hepatotoxic determined a decrease of the albumin content from 5,28 $\pm 0,05 \mathrm{~g} / \mathrm{l}$ in the witness lot to 30,6 $\pm 0,8 \mathrm{~g} / \mathrm{l}(\mathrm{P}<0,05)$. Coptisine bisulfate in doses of $10 \mathrm{mg} / \mathrm{kg}$ and $20 \mathrm{mg} / \mathrm{kg}$, when administered for 7 days, corrected the $\mathrm{CCl}_{4}$ induced hypoproteinemia. The albumin level in the 14th day in animals with ATH and the ones treated with coptisine bisulfate was at the level of the witness lot (tab. 5). 
Tabel 5. The modification of the cholesterol level, total proteins and albumin in serum in carbon tetrachloride induced HT and coptisine bisulfate 10 and $20 \mathrm{mg} / \mathrm{kg}$ usage

\begin{tabular}{|l|c|c|c|c|}
\hline \multicolumn{1}{|c|}{ Animal groups } & $\begin{array}{c}\text { Nr. Of } \\
\text { animals }\end{array}$ & $\begin{array}{c}\text { Total } \\
\text { cholesterol } \\
\text { mmol/l }\end{array}$ & $\begin{array}{c}\text { Total protein } \\
\text { g/l }\end{array}$ & Albumin \\
\hline 1. The witness lot & 7 & $5,09 \pm 0,04$ & $58,3 \pm 0,5$ & $35,5 \pm 0,8$ \\
\hline 2. CCl ${ }_{4}$ after 7 days & 7 & $5,03 \pm 0,07$ & $58,3 \pm 0,6$ & $30,6 \pm 0,8$ \\
& & $\mathrm{P}_{1-2>0,05}$ & $\mathrm{P}_{1-2>0,05}$ & $\mathrm{P}_{1-2<0,05}$ \\
\hline 3. CCl ${ }_{4}+$ coptisine bisulfate $10 \mathrm{mg} / \mathrm{kg} \mathrm{7}$ & 7 & $4,97 \pm 0,07$ & $60,3 \pm 0,8$ & $34,3 \pm 0,4$ \\
days & & $\mathrm{P}_{1-3>0,05}$ & $\mathrm{P}_{1-3>0,05}$ & $\mathrm{P}_{1-3>0,05}$ \\
& & $\mathrm{P}_{2-3>0,05}$ & $\mathrm{P}_{2-3>0,05}$ & $\mathrm{P}_{2-3<0,05}$ \\
\hline 4. $\mathrm{CCl}_{4}+$ coptisine bisulfate $20 \mathrm{mg} / \mathrm{kg} 7$ & 7 & $4,98 \pm 0,02$ & $58,5 \pm 0,9$ & $33,2 \pm 0,6$ \\
days & & $\mathrm{P}_{1-4>0,05}$ & $\mathrm{P}_{1-4>0,05}$ & $\mathrm{P}_{1-4<0,05}$ \\
& & $\mathrm{P}_{2-4>0,05}$ & $\mathrm{P}_{2-4>0,05}$ & $\mathrm{P}_{2-4<0,05}$ \\
& & $\mathrm{P}_{3-4>0,05}$ & $\mathrm{P}_{3-4>0,05}$ & $\mathrm{P}_{3-4>0,05}$ \\
\hline 5. CCl ${ }_{4}$ after 14 days & 7 & $5,28 \pm 0,05$ & $59,2 \pm 0,7$ & $35,1 \pm 0,3$ \\
& & $\mathrm{P}_{1-5<0,05}$ & $\mathrm{P}_{1-5>0,05}$ & $\mathrm{P}_{1-5>0,05}$ \\
\hline 6. CCl ${ }_{4}+$ coptisine bisulfate $10 \mathrm{mg} / \mathrm{kg}$ & 7 & $5,06 \pm 0,03$ & $60,3 \pm 1,4$ & $34,3 \pm 1,3$ \\
14 days & & $\mathrm{P}_{1-6>0,05}$ & $\mathrm{P}_{1-6>0,05}$ & $\mathrm{P}_{1-6>0,05}$ \\
& & $\mathrm{P}_{5-6<0,05}$ & $\mathrm{P}_{5-6>0,05}$ & $\mathrm{P}_{5-6>0,05}$ \\
\hline 7. CCl ${ }_{4}+$ coptisine bisulfate $20 \mathrm{mg} / \mathrm{kg}$ & 7 & $5,18 \pm 0,11$ & $58,9 \pm 0,6$ & $35,1 \pm 0,7$ \\
14 days & & $\mathrm{P}_{1-7>0,05}$ & $\mathrm{P}_{1-7>0,05}$ & $\mathrm{P}_{1-7>0,05}$ \\
& & $\mathrm{P}_{5-7>0,05}$ & $\mathrm{P}_{5-7>0,05}$ & $\mathrm{P}_{5-7>0,05}$ \\
& & $\mathrm{P}_{6-7>0,05}$ & $\mathrm{P}_{6-7>0,05}$ & $\mathrm{P}_{6-7>0,05}$ \\
\hline
\end{tabular}

According to the obtained results, coptisine bisulfate, one of Chelidonium majus alkaloids is a component that lacks in systemic toxicity, owns hepatoprotective properties through re- establishing the transaminases activity, reducing the Ritis coefficient and normalizing the cholestasis in acute toxic hepatitis induced by carbon tetrachloride. This fact indicates its contribution to pharmacological effects of celandine extracts and the possibility of using of this product in the complex treatment of toxic hepatitis.

Conclusions.

1. Coptisine bisulfate, in doses of $10 \mathrm{mg} / \mathrm{kg}$ and $20 \mathrm{mg} / \mathrm{kg}$, in a dose dependent way, annihilated the cytolisis syndrome by reestablishing the transaminases activity, esspecially ALAT, and the obvious decrease of the Ritis ratio.

2. It was established the reduction of cholestasis under the influence of coptisine bisulfate by non esential growth of alkaline phosphatase activity and of total, direct and indirect bilirubin level, (decrease of FA/ALAT ratio) and modulated the metabolic parameters deflection of acute toxic hepatitis.

3. When administered for 7 and 14 days, coptisine bisulfate in strenghts of $10 \mathrm{mg} / \mathrm{kg}$ and 20 $\mathrm{mg} / \mathrm{kg}$, normalises the LDH content at the level or witness lot animals, but the blood glucose level induced by the hepatotoxic substance was not influenced.

4. Coptisine bisulfate corrected the hypoproteinemia caused by $\mathrm{CCl}_{4}$, when administered for 7 days and normalised the albumin level in the 14th day of treatment of the ATH animals.

\section{REFERENCES}

1. Casian I., Casian A. "Izolarea coptizinei din herba de rostopască (Chelidonium majus 1.)". Certificat de înregistrare a obiectelor dreptului de autor şi drepturilor conexe Seria OȘ Nr. 3195 din 08.09.2011.

2. Maji A.L., Pratim B. Chelidonium majus L. (Greater celandine) - A Review on its Phuytochemical and therapeutic Proprietives. International journal of Herbal medicine. 2015; 3(1): 10-27.

3. Peredelcu R.A. Acute toxicity of coptisine. In: IX Ukrainian International Scientific Conference: Current Aspects of Clinical Pharmacology According to Evidence-based Medicine Achievements.- 16-17 November, 2017.- Vinnytsia, Hilan-LTD: BHMY, 2017, c. 83-90. ISBN 978-966-924-657-8

4. Peredelcu, R.A., Gonciar V.I., Scutari C.D. Acute toxicity research of coptizine. In: New achievements of world science. Proceedings of VII International scientific conference "New achievements of world science”. Jun 22, 2017, Morrisville, Lulu Press., 2017, p. 90. ISBN 978-1-387-08722-8.

5. Ye X.et al. Hepatoprotective effects of Coptidis rhizoma aqueous extract on carbon tetrachloride-induced acute liver hepatotoxicity in rats. J Ethnopharmacol. 2009 Jul 6;124(1):130-6.

6. Zielińska S.et al. Greater Celandine's Ups and Downs-21 Centuries of Medicinal Uses of Chelidonium majus From the Viewpoint of Today's Pharmacology. Front Pharmacol. 2018; 9: 299. 